удк 378

Юрій Стежко

Національний авіаційний університет

ORCID ID 0000-0002-0226-8081

DOI 10.24139/2312-5993/2020.01/116-127

\title{
МОТИВАЦІЙНІ ДОМІНАНТИ ТА МЕТОДОЛОГІЧНІ ЗАСАДИ ОСВІТНІХ ІННОВАЦІЙ В ІМПЕРАТИВАХ УКРАЇНСЬКИХ РЕАЛІЙ
}

у статті обгрунтовується актуальність дослідження інноваційного розвитку освіти як стратегічного ресурсу суспільно-економічного розвитку країни. Наразі за мету нашого дослідження обираємо висвітлення ціннісно-мотиваційної компоненти особистісної компетентності, розширення уявлень про об'єктивні та суб'єктивні чинники впливу на інноваційні процеси, визначення методологічних засад парадигмальних трансформачій освіти. Наскрізною ідеєю статті є визначальна роль мотиваційної сфери у формуванні компетентності. Простежується обумовленість внутрішніх мотивів зовнішніми чинниками. Досягнуті результати орієнтовані на практичне втілення в царину педагогічної інноватики.

Ключові слова: освіта, менеджент, інновація, компетентність, компетенція, мотивація, методологічний плюралізм.

Постановка проблеми. Про потребу в інноваційному розвитку освіти мовиться на різних владних щаблях протягом усього часу незалежності України. Проте реальні кроки по шляху реалізації інноваційного розвитку освіти Україна робить лише з позиціонуванням себе європейською країною, усвідомленням, що освіта становить стратегічний потенціал економічного розвитку. Не $\epsilon$ новиною, що в розвинених країнах «кожна інвестована в освіту одиниця витрат, як правило, дає не менше чотирьох одиниць прибутку, вираженого в грошовій формі» (Освітологія, 2013, c. 557). Проте інвестування в нереформовану освіту, за неефективного менеджменту було 6 марнотратством. Українська університетська освіта наразі потребує не імітації оновлення, а ефективного менеджменту, глибоких змін, передусім у свідомості державної еліти.

Ринкова економіка піднесла на рівень імперативності такі вимоги до сучасного випускника університету як ініціативність, професіоналізм, прагматизм мислення. Саме на ідеології результативності реалізації знань має ґрунтуватися компетентнісна модель вищої освіти. Прете самі кращі проєкти можуть залишитися на рівні намірів, якщо не буде врахована мотиваційна складова компетентності, фактор зацікавленості особистості в професійному становленні, в індивідуальному успіху. Як зазначає С. Бондар, «...компетентність - це здатність особистості діяти. Але жодна людина не діятиме, якщо вона особисто не зацікавлена в цьому. Природа компетентності така, що вона може проявлятися лише в органічній єдності з цінностями людини, тобто в умовах глибокої особистісної зацікавленості в даному виді 
діяльності...» (Бондар, 2003, с. 9). Зазначене й актуалізує дослідження, як на нас, обділеного увагою психолого-педагогічного аспекту компетентнісної моделі та методологічних засад інноваційного розвитку освіти.

Аналіз актуальних досліджень. Вивчення наукової літератури свідчить, що проблема інноваційного розвитку освіти в теоретичному, психолого-педагогічному, організаційному та управлінському аспектах знаходиться в полі зору видатних вітчизняних учених. Відзначаються фундаментальні дослідження з філософії освіти, стратегії ії інноваційного розвитку, новітніх технологій таких фундаторів освітології як В. Андрущенко, В. Кремень, В. Огнев'юк. Втілення світового досвіду, ідей Болонського процесу маємо в роботах теоретиків вищої освіти М. Степка, В. Лугового, С. Ніколаєнка, С. Сисоєвої, які плідно розробляють інтерактивні технології навчання, теоретичне та методологічне забезпечення компетентнісного навчання. Ідея поєднання освітнього процесу з вихованням, проблема духовного становлення особистості знайшли своє відображення в публікаціях О. Сухомлинської. Чільне місце в дослідженнях компетентнісної моделі вищої освіти посідають здобутки В. Лугового, О. Савченко, Л. Хоружої, О. Часнікової. Окрім зазначених дослідників, у різних зрізах проблемою інноваційного розвитку освіти опікуються такі вчені, як О.Ареф'єва, С. Бєляков, Т. Білобровко, О. Висоцька, І. Грищенко, О. Іншаков, І. Каленюк, Г. Клімова, В. Олійник, О. Падалка, М. Скиба та інші. В цілому вивчення наукової літератури з проблеми інноваційного розвитку освіти та компетентнісної моделі зокрема дало нам розуміння всієї глибини та всебічності завдань, які стоять перед педагогічною наукою.

Назагал, маємо констатувати, що наразі доволі докладно висвітлені проблеми організаційно-управлінських інновацій, економіки освіти, проте, як на наш погляд, бракує робіт із вивчення такого важливого аспекту інноваційного розвитку освіти як мотиваційне забезпечення особистісної компетентності. Незавершеними бачаться й концептуалізація педагогічної інноватики та осучаснення методології її дослідження. Окрім того, як супутні основному напряму дослідження потребують свого контекстуального уточнення в заломленні на університетську освіту такі поняття, як «компетентність» та «компетенція».

Відтак за мету нашого дослідження обираємо висвітлення ціннісномотиваційної компоненти особистісної компетентності, розширення уявлень про об'єктивні та суб'єктивні чинники впливу на інноваційні процеси, визначення методологічних засад парадигмальних трансформацій освіти.

об’єктом дослідження маємо компетентнісну модель інноваційного розвитку освіти.

Основними методами дослідження є зіставний аналіз, методи аналогії та сходження від абстрактного до конкретного. При цьому ми спиралися на емпіричний матеріал, наведений у працях відомих педагогів, психологів. 
За методологічну основу маємо синергетичне бачення освіти як складної дисипативної системи, розвиток якої відзначається як об'єктивною закономірністю, так і суб'єктивною непередбачуваністю, визнання багатовимірності інноваційного запровадження якісно нової парадигми освіти.

Виклад основного матеріалу. Постіндустріальний уклад обернувся інформаційним виміром суспільного буття, новою формою інтелектуалізму, новими критеріями елітарності, за яких особистісною цінністю постає компетентність. Наразі загострилася потреба в переорієнтації освітніх технологій з накопичення абстрактних знань на результативну їх реалізацію, на ринковий прагматизм. Утім не всі однаково оцінили постмодерністську інтерпретацію раціональності як репрезентета прагматизації у ставленні до дійсності. Тому за окремими оцінками наразі маємо невтішний стан освітнього рівня суспільства, обумовлений цивілізаційними процесами. За твердженням І. Гобозова, «глобалізація й постмодернізм призвели до різкого зниження інтелектуального рівня сучасного соціального світу» (Гобозов, 2015, с. 41). О. Висоцька звертає увагу на негативні тенденції в освіті, пов'язуючи їх із комп'ютеризацією, запровадженням електронних носії інформації. «Комп'ютеризація суспільства, - пише вона, - призвела до трансформації характеру збереження та передання інформації, що, безумовно, спричинило низку криз в освіті - від кризи читання й письма, виникнення проблем запам'ятовування, розсіювання уваги та зниження порогу сприйняття текстового навчального матеріалу ...» (Висоцька, 2018, с. 3), що можна тлумачити як натяк на комп'ютерний стиль мислення. Невтішно оцінює сучасний стан освіти і А. Запєсоцький, кажучи, що ії руйнація $є$ закономірним процесом. На його думку, негативні явища в освіті $€$ спільними для багатьох країн і пов'язані вони з феноменом постмодернізму, зокрема, 3 проявами деконструктивізму, деінтелектуалізації суспільства, втратою мотивації на знання та будь-які інновації в освіті. Не останню роль у цьому відіграє насадження засобами масової інформації ідеології всесилля грошей, цінностей «людини-споживача» (Запесоцкий, 2013, с. 27). Звісно, важко йому заперечити щодо втрати мотивації на знання за умов капіталізації суспільства. Проте й убачати в споживацьких настроях лише нестачу інтелекту не варто. Досвід розвинених країн дає нам зразки спрямування орієнтації особистості на споживання як цінність у русло мотивації до здобуття професійної компетентності, прагматизації знань, а українська деінтелектуалізація, як випливає зі слів А. Запєсоцького, стоїть в одному ряду зі світовою. Погодьмося з думкою І. Гобозова: «Знання в постіндустріальну епоху виробляються не для того, щоб їх відправити в архів, а для того, щоб продавати. Знання - це гроші. Причому цими знаннями розпоряджається не держава, а приватні особи» (Гобозов, 2015, с. 48). Отже, якщо «знання - це гроші», то орієнтація людини на споживання, за певних умов, цілком може стати заохоченням до оволодіння знаннями, до професійного становлення. 
Назагал важко заперечити негативні моменти в освіті, проте вони не становлять нездоланну перепону інноваційному розвитку, не $\epsilon$ визначальними. Важелі впливу на рівень сукупного національного інтелекту зосереджені в менеджменті. Ключовим елементом результативності освіти наразі $€$ мотиваційна компонента на інноваційність, компетентність, яка $€$ прерогативою освітянського менеджменту всіх рівнів, з одного боку, а з іншого - створення суспільного попиту на знання, забезпечення умов задля професійної самореалізації випускника університету, що має бути в пріоритеті державного менеджменту. При цьому тримаймо в полі зору, що зовнішні мотиватори обумовлюють суб'єктивну мотивацію, а їх узгодженість з установками суб'єкта на самореалізацію забезпечує ефект синергії. У такому разі з усією очевидністю виявится неправомірність тверджень щодо деінтелектуалізації сучасного випускника університету..

Менеджмент мав би вчасно та продуктивно відреагувати на комп'ютеризацію навчальних технологій, за якої на зміну запам'ятовуванню великих масивів інформації цілком закономірно, як ми уже зазначали, «..прийшов інтелектуалізм більш високого ґатунку створення штучного інтелекту, комп'ютерних систем, здатних не лише вивільнити мислення людини від запам'ятовування рутинної інформації, але й до продукування інформації на рівні людської творчості. Сучасний студент цілком виправдано не буде витрачати час і зусилля на усне обрахування, запам'ятовування інформації, а радше створить відповідну програму, що є свідченням на порядок вищого рівня інтелекту, ніж умінь до усного обчислення чи сприйняття тексту» (Стежко, 2019, с. 18). Аналітики від освіти, а за ними й освітянський менеджмент не змогли вчасно розпізнати новий інтелектуалізм, прийнявши його за деінтелектуалізм, тож згаяли час на корегування самої методології оцінки освітніх інновацій. Ще й досі неважко зустріти в науково-педагогічних колах хибне уявлення про компетентність - як сукупне володіння абстрактними знаннями, вважаючи, що чим їх більше, тим компетентнішою є особа. Втішає те, що за новими регламентуючими освіту документами МОН визнання рейтингу закладу освіти став критерій успішності випускників у реалізації своєї фаховості в українському секторі економіки, показник просування соціальним ліфтом.

Надалі ми маємо намір розглянути умови, за яких формується компетентна, орієнтована на економічний прагматизм особистість випускника університету. 3 прикрістю маємо констатувати, що наразі профільні відомства, відповідальні за освіту, не призвичаїлися до умов ринку в царині освітніх установ, за якого домінуючим чинником на оволодіння фаховою компетентністю $\epsilon$ мотивація. Відтак нехтування державним менеджментом таким потужним важелем впливу на 
оволодіння компетентністю як мотивація спричинило стан, що вітчизняна економіка залишилася без уваги з боку найбільш обдарованих випускників університетів. Наразі чи не єдиним чинником особистісної зацікавленості в компетентності для успішного випускника університету $\epsilon$ можливість гідно самореалізуватися за кордоном. Про орієнтацію на європейські перспективи професійної реалізації свідчать як результати опитування, так і підвищений інтерес до вивчення іноземних мов. А чи $є$ перспективи гідної професійної самореалізації на теренах України? Як на нас, далеко не такі, як хотілося б. Проте, гадаємо, що створити такі умови не становить особливих труднощів та й витрат. І мотивація студентства на професійну самореалізацію в структурах вітчизняної економіки має формуватися ще з університетської лави аукціоном вакансій, державними та приватними замовленнями, стипендіальним стимулюванням тощо.

Наразі університетське студентство має залучатися до перенесення наукових ідей з навчальних лабораторій до реального сектору економіки. Держава має забезпечити доступність до участі в реальних проєктах економічного розвитку (на кшталт програми ЄC «Horizon 2020»), які розкривають можливості втілення інноваційних ініціатив. Задля цього варто подолати консерватизм мислення освітянського топ-менеджменту, бачення університету лише як інституту продукування знань, не завжди орієнтованих на забезпечення сьогочасних поточних потреб економіки в технологіях тощо. Щоб Україна не опинилася в ролі європейського економічного аутсайдера, університет має чинити не навздогін економічним запитам, а на випередження - він має стати інститутом стратегічного проєктування виходу країни на рівень провідних економік світу й політичного дороговказу - в широкому розумінні поняття «політика». А ресурсом дороговказу має бути перспективне забезпечення відповідними фахівцями. Зазначене розв'язує і питання мотивації на навчання. Бачення реальних, а не уявних перспектив професійної реалізації - чи не найпотужніший мотив на компетентність. Скажімо, задекларований перехід економіки України на рейки високотехнологічного виробництва вже мав би віднайти відображення в університетських програмах. Зволікання з підготовкою фахівців відповідної компетентності може обернутися непоправними втратами. На заваді такого випереджаючого відображення дійсності, перспективного проєктування постала інерційність освітянської системи та знову ж таки брак мотивації на втілення інновацій як у професорсько-викладацького складу, так і в освітянського менеджменту.

Зрушення в бік активності може дати міжуніверситетська конкуренція, але не в гонитві за абітурієнтом, як це ми маємо зараз, а у змаганні за якість знань випускника, - яка має оцінюватися за результативністю його післядипломної діяльності, кар'єрним ростом тощо. Задля цього університети стануть конкурувати між собою в залученні до 
своїх лав ефективних педагогів, продуктивних науковців. Сподівання на конкуренцію між університетами в підвищенні якості освіти шляхом збільшення кількості університетів та урізноманітнення форм власності, на жаль, не виправдалися, як не виправдала себе й комерціалізація освіти. Надія, що студент, який платить за навчання, буде вмотивований на отримання високого рівня знань, так і залишилася лише надією.

Наразі університетська освіта має відмовитися від масовості, стати елітарною, а відбір студентства має відбуватися протягом усього терміну навчання - за якістю знань, здатністю до науково-дослідної роботи, ініціативністю, а головно, орієнтованістю на результативність діяльності. Пам'ятаймо, масовість - контроверза компетентності.

Що наразі стало на заваді успішній реалізації інновацій в освіті? Передусім, неоднозначність у розумінні термінів «інновація» та «компетентність», а відтак і маємо, що задекларований інноваційний розвиток освіти на практиці зводиться до дріб'язкових змін у освітньому процесі та й то не завжди прогресивної результативності, що лише дискредитує саму ідею інноваційного розвитку. А дійсно парадигмальні трансформації не мисляться без відповідного методологічного переосмислення інноваційного процесу. Отже, надалі ми й звернемося до дослідження зазначених двох, як на нас, визначальних чинників.

Аналіз наукової літератури свідчить, що проблема концептуалізації термінів «інновація» та «компетентність» не полишає поле філософського та педагогічного дискурсу. Скажімо, словник С. Ожегова визначає інновацію як щось уперше створене, маловідоме, те, що щойно виникло замість традиційного. Соціолого-педагогічний словник укладачів С.Гончаренка, В. Радула та інших тлумачить інновацію як «запровадження нових форм організації праці й управління, що охоплює не тільки окреме підприємство, але й їхню сукупність» (Сочіолого-педагогічний словник, 2004, с. 91). Як бачимо, сам термін «інновація» має широке поле вжитку в різноманітних сферах бутт, проте в наведених визначеннях ані словом не згадується ефективність «вперше створеного». Нововведення ще не означає а-priori прогресивності щодо традиційного. Тож, нам більш імпонує характеристика інновацій, наведена в Енциклопедії професійної освіти за ред. С. Батіщєва: «Інновації - це такі актуально значущі та здатні до системної самоорганізації новоутворення, що виникають на основі різноманітності ініціатив і нововведень, котрі стають перспективними для еволюції освіти та позитивно впливають на ії розвиток, а також на розвиток більш широкого мультикультурного простору освіти» (Энциклопедия професссионального образования, 1998, с. 370). Тобто мовиться про неодмінність якісних перетвореннь. Загальноприйтнято вживати термін «інновація» для позначення фундаментальних перетворень зі зміною самої методології розбудови освіти. Намагання вибудовувати нову парадигму освіти на 
застарілих методологічних засадах приречені на неуспіх. Кожна якісно нова освітня парадигма виникає на тлі пануючої педагогічної моделі завдяки оновленню теорії, методів, організаційно-управлінських заходів і передусім методологічних засад. Інноваційна компетентнісна модель освіти також потребує осучаснення теоретико-методологічного забезпечення, такої методології, яка б розкривала суб'єктивному фактору спектр можливостей у виборі форм і засобів впливу.

Наразі в постмодерністському педагогічному дискурсі визрів новий підхід до освітніх трансформацій, заснований на синергетичній концептуалізації розвитку, за якої розвиток визначається не догматами раціональних закономірностей, не принципами однозначності та об'єктивної обумовленості, а ірраціоналізмом, необмеженим плюралізмом, сутнісним релятивізмом і суб'єктивністю, що межує із суб'єктивізмом. На практиці це означає, що не може панувати лише одна теорія чи один підхід до втілення інновації - створюється спектр можливостей, сценаріїв, (аттракторів), які обумовлюють парадигмальні зміни освіти. Тобто йдеться про методологію на кшталт - «дозволено все» - сполучення об'єктивних чинників детермінації із суб'єктивним вибором, закономірного й випадкового тощо. Ось як мисляться методологічні засади С.Гончаренком та В.Кушніром: «Педагогічному процесу властивий поліцентризм... Це означає, що не може бути панівною в ньому одна теорія, парадигма, один метод чи підхід... Вибір методології визначається тим, яким чином у нашій ментальності постає світ... Розв'язанням «системної кризи» повинно стати визнання багатовимірності (педагогічного процесу - авт.) і права дослідника на різні логіки і різні парадигми» (Гончаренко, Кушнір, 2005, с. 3). У заломленні на інноваційний розвиток освіти зазначене розкриває весь багатогранний потенціал суб'єктивного фактору, необмежені можливості для дієвих ініціатив широких верств теоретиків і практиків. Інноваційна ефективність обумовлена тим, що кожна методологічна настанова, кожен учасник втілення інновацій мають паритет щодо впливу на перебіг освітянського процесу, і на одному етапі один суб'єкт чи засіб впливу може стати провідним чи навіть панівним, а на іншому - поступитися впливом на користь іншого чинника чи суб'єкта. Педагог може використовувати чи поєднувати різні конструкції компетентнісного підходу в освіті - як раціональні, так і ірраціональні алгоритми освітнього процесу. Показником узгодженості різних векторів впливів на кожному кроці парадигмальних змін $€$ загальна результативність, у нашому контексті - це рівень компетентності особистості. Логічно виникає питання, чим вимірювати ефективність інновації, за якими критеріями оцінювати компетентність особистості. Шукаючи відповідь на це питання, ми неминуче натикаємося на проблему визначення самої компетентності та ії структури. Говорити про мотивацію на компетентність без чіткого уявлення, що то $€$ компетентність, недоречно. А власний досвід дає нам право 
говорити, що не лише в колі практиків, але й серед теоретиків доволі часто доводиться стикатися з нерозумінням відмінностей між компетентністю та компетенцією. Тож спробуємо пролити світло.

Задля уточнення нашого контекстуального вжитку поняття «компетенція» наведемо лише два із широкого спектру визначень. Зокрема, Ф.Шаріпов наводить визначення, яке імпонує нам тим, що розкриває не лише зміст компетентності, але і їі структуру, їі зв'язок із компетенціями. «Компетентність, - пише він, - це сукупність рис (характеристик) особистості, що дозволяють їй якісно виконувати визначену діяльність, що направлена на розв'язання проблем (завдань) у певній галузі. Компетентність - це те, чого досяг конкретний спеціаліст, вона характеризує міру освоєння компетенції ...» (Шарипов, 2010, с. 73). Більш докладно структурну будову, а точніше взаємозв'язок компетентності та компетенції розкривають слова Дж. Равена: «Ми переконалися, що компетентність складається 3 великої кількості компонентів, багато з яких відносно незалежні один від одного..., і що ці компоненти компетентності можуть значною мірою заміщувати один одного в якості складових ефективної поведінки. Чим більше таких компонентів залучає людина в процес досягнення значимих для себе цілей, тим вища ймовірність, що вона цих цілей доб'ється» (Равен, Дж., 2002, с. 253). Цими «компонентами компетентності» $€$ компетенції, сукупність яких як засобів практичної реалізації знань визначає рівень професійності. І що більше компетенцій, то вищою $є$ продуктивність практичної діяльності. Компетентність $€$ похідною від компетенцій, тож $€$ системою - що означає певну взаємообумовленість і підпорядкованість компетенцій, завдяки чому компетентність набуває якостей, не притаманних жодній 3 окремих компонент - компетенцій. Тобто ефективність системності визначається не принципом редукції, а радше феноменом синергії, коли загальна ефективність системи компетенцій перевищує простий сумарний ефект кожної з них. Останнє положення підводить нас до питання - а які ж компетенції $\epsilon$ ймовірно найбільш впливовими щодо мотивації на компетентність? Відповідь варто шукати в ціннісних орієнтаціях самої особистості. У зв'язці мотивації та компетенції визначальною є мотивація. У більшості випадків мотивацію становить суспільне визнання, самоутвердження особистості щодо оточення. Це обумовлено самою сутністю людини - ії соціальністю.

Особистість самореалізується не ізольовано від соціального середовища, а в колективі, тож якою 6 самодостатньою людина не видавалася, вона не може залишатися байдужою до суспільної оцінки їі компетентності, результативності діяльності. А це спонукає особистість до оволодіння поряд із професійною компетенцією такими якостями як громадянськість, моральність, комунікативність, толерантність, командна 
робота. В цьому контексті повчальним видається досвід європейських країн, зокрема, імплантації в програму освіти інтегративного курсу «соціальні технології»; він охоплює широке коло компетенцій: громадянських, комунікативних, економічних, фінансових, public relations тощо, кожна з яких становить підґрунтя для продуктивної реалізації професійної компетентності.

Проте особистісна зацікавленість як внутрішня мотивація може виникати лише на ґрунті бачення реальних можливостей самореалізації в обраному виді діяльності. Внутрішня мотивація обумовлена зовнішніми чинниками. Тож вмотивованість особистості залежить від узгодженості власної та суспільної системи цінностей. Іншими словами, важливо, наскільки особистість усвідомлює суспільний попит на власну компетентність та засоби ії реалізації. Відтак, мотивація має постійно підживлюватися запитами на професійність, створенням системи заохочень на нарощування компетентності. І чим більше мотиваторів, тим глибша та стійкіша мотивація. Задля цього влада, громадянське суспільство мають здійснювати моніторинг запитів, потреб, ціннісних орієнтацій студентства та створювати відповідні умови заохочення до самореалізації в царині вітчизняної, а не закордонної економіки.

Звісно, мотивація не підпадає під якесь узагальнення, підвладне адмініструванню, проте певну ієрархію ціннісних орієнтацій молодих фахівців можна та й варто вибудувати як керівництво для дії. За декотрими дослідженнями наразі в особистісних ціннісних орієнтаціях ринкового суспільства панує культ матеріальних статків, а отже домінуючого положення набули кар'єрний ріст, провладні устремління тощо, які обумовлюють матеріальне забезпечення.

I наостанок. Маємо бути свідомими того, що навіть за найкращого збігу обставин багатофакторність інноваційного розвитку освіти, відсутність чіткого суспільного замовлення на компетентну особистість, а також бюджетна архітектоніка держави не залишають сподівань на швидкий результат. Проте ефективний менеджмент тим і ефективний, що приймає вірні рішення в складних умовах. Такими кроками могли би бути оптимізація зовнішнього адміністрування та університетського самоврядування, організація фандрайзингу задля реалізації найбільш перспективних проєктів розвитку університетів тощо.

Результати дослідження полягають, по-перше, у контекстуальному уточненні таких понять як інновації в освіті, компетентність, компетенція; по-друге, в обґрунтуванні визначальної ролі мотивації щодо компетентності, обумовленості внутрішніх мотивів зовнішніми спонуками до оволодіння компетентністю; по-третє, у визначенні методологічного плюралізму, кореляції об'єктивних закономірностей та суб'єктивних чинників у новій парадигмі освіти як імперативів освітянських інновацій. 
Висновки та перспективи подальших наукових розвідок. Назагал із зазначеного можна зробити висновки: що стратегія інноваційного розвитку освіти розв'язує чи не винятково значиме завдання: посісти Україні гідне місце у співдружності європейських країн; що університет $\epsilon$ інститутом не лише задоволення поточних запитів економіки, але й перспективного проєктування її розвитку; що альтернативи інноваційному розвитку освіти наразі немає; що в цьому процесі домінуючим $\epsilon$ суб'єктивний фактор; що на заваді втілення компетентнісної моделі освіти (а не іiї імітації) $€$ латентний консерватизм мислення, відсутність міжуніверситетської конкуренції за ефективного науковця, викладача та продуктивного випускника; і головне - що прискорене реформування освіти залежить, передусім, від створення системи мотивації, заохочень освітянського менеджменту.

I насамкінець. Постіндустріальна доба добігає кінця, невдовзі прийде нова епоха, яка постане перед освітою новими викликами. Тож тема інновацій в освіті $€$ невичерпною і щоразу вимагатиме розв'язання нових завдань. I не треба бути великим провидцем, щоб не угледіти, як потребу в поточній корекції вже напрацьованих рекомендацій, так і пролонгацію проблеми освітніх інновацій уже за нових цивілізаційних умов.

\section{ЛІТЕРАТУРА}

Бондар, С. (2003). Компетентність особистості - інтегрований компонент навчальних досягнень учнів. Біологія і хімія в школі, 2, 8-9. (Bondar, S. (2003). Personality Competence - an Integrated Component of the Studying Achievements of Pupils. Biology and Chemie at School, 2, 8-9).

Висоцька, О. (2018). Педагогічні інновації в контексті викликів XXI століття. Філосодрія, теорія та практика випереджаючої освіти для сталого розвитку. Ч. І. Дніпро: СПД «Охотнік», 3-5. (Vysotska, 0. (2018). Pedagogical Innovations in the Context of the Challenges of the 21st Century. The Philosophy, a Theory and a Practice of the Education with the Advance for Sustainable Development, part 1. Dnipro: SPD «Okhotnik», 3-5).

Гобозов, И. (2015). Постмодернизм - епоха медиократов. Вопросы философии, 12, 4153. (Gobozov, I. (2015). Postmodernism is the Epoch of the Mediocracts. Guestion of Philosophy, 12, 41-53).

Гончаренко, С., Кушнір, В. (2005). Педагогічний процес з погляду «філософії XXI ст.» Шлях освіти, 1, 2-7. (Honcharenko, C., Kushnir, V. (2005). The Process Pedagogical from a «XXI Century Philosophy» Sight. The Way of Education, 1, 2-7).

Запесоцкий, А. (2013). Философия образования и проблемысовременных реформ. Вопросы философиu, 1, 24-33. (Zapesockij, A. (2013). Philosophy of Education and Problems of the Reforms of Today. Guestion of Philosophy, 1, 24-33).

Огнев'юк, В., Сисоєва, С. (ред.) (2013). Освітологія: хрестоматія. Київ: ВП «Едельвейс». (Ohnev'iuk, V., Sysoieva, S. (Ed.) (2013). The Educology: Chrestomathie. Kiev: Edelweis).

Равен, Дж. (2002). Компетентность в современном обществе: выявление, развитие и реализацияю. Москва: Когито-Центр. (Raven, Dzh. (2002) The Competence in the Modern Society: a Define, a Development, a Realization. Moscow: Kogito-Center). 
Радул, В. (ред.) (2004). Соціолого-педагогічний словник. Київ: «ЕксОб». (Radul, V. (Ed.) (2004). The Sociology and Pedagogical Dictionary. Kyiv: «ExOb»).

Стежко, Ю. (2019). Подання інформації в комп'ютерно-орієнтованих освітніх технологіях та їі експлікація в імперативах постмодернізму. Information Technologies and Learning Tools, 3-71, 12-22. (Stezhko, Yu. (2019). Vision of Information in the Computer Oriented Educational Technologies and its Explication in the Imperatives of Postmodernism. Information Technologies and Learning Tools, 3-71, 12-22). Retrieved from: https://journal.iitta.gov.ua/index.php/itlt/issue/view/100/

Шарипов, Ф. (2010). Профессиональная компетентность преподавателя вуза. Высшее образование сегодня, 1, 72-77. (Sharipov, F. (2010). A Professional Competence of a Lecturer. Higher Education Today, 1, 72-77).

Батышев, С. (ред.) (1998). Энциклопедия профессионального образования: В 3-х т. Т. 1. Москва: АПО. (Batyshchiev, S. (Ed.) (1998). The Vocational Education Encyclopedia: In 3 vol. Vol. 1. Moscow: APO).

\section{PEЗЮME}

Стежко Юрий. Мотивационные доминанты и методологические основания образовательных инноваций в императивах украинских реалий.

В статье обосновывается актуальность исследования инновационного развития образования как стратегического ресурса общественно-экономического развития страны. Целью исследования является освещение ценностномотивационной компоненты личностной компетентности, расширение представлений об объективных и субъективных фракторах влияний на инновационый процесс, определение методологических основ парадигмальних трансформацій образования. Сквозной идеей статьи является определяющая роль мотивационной сфреры в формировании компетентности. Прослеживается обусловленность внутренних мотивов внешними фракторами. Достигнутые результаты ориентированы на практическое воплощение в область педагогчческой инноватики.

Ключевые слова: образование, менеджент, инновация, компетентность, компетенция, мотивация, методологический плюрализм.

\section{SUMMARY}

Stezhko Yurit. Motivation dominants and methodological basis of the educational innovations in the imperatives of Ukrainian realities.

The article substantiates the relevance of research on the innovative development of education as a strategic resource for socio-economic development of the country. The aim of the study is to highlight the value-motivational component of personal competence, to expand the perceptions of objective and subjective factors of paradigmatic changes and to determine methodological foundations of innovative development of education. Methods of research: comparative analysis, methods of analogy and ascent from abstract to concrete. According to the methodology we have: the vision of education as a complex dissipative system the development of which is determined by objective laws and subjective unpredictability; recognition of the multidimensionality of innovative introduction of a qualitatively new paradigm of education. Throughout the idea of the article is the determining role of the motivational sphere in the formation of competence. By its nature competence is a derivative of goals, meanings, values orientations, personal interest in the chosen type of activity. It is possible to observe the condition of internal motives by external 
factors. The depth and stability of motivation are determined by the correlation of value orientations, aspirations of the individual with the external conditions of the implementation of competence. It is noted that the new methodological foundations of postmodernism significantly influenced the innovative development of education. Instead of dogmatism, we have relativism: the principle of objectivity, unambiguity of determination, logic has changed to unlimited pluralism, essential relativism, subjectivism, irrationalism, etc. Based on the analysis of key factors determining the innovative development of education, the main results of work are formulated: firstly, clarification (in accordance with the context) of such concepts as innovations (in education), competence, competency and their interconnection; secondly, the scientific substantiation of the determining role of motivation in the formation of competence, the definition of the reasons for internal motives for mastering competence in external requests; thirdly, in defining methodological pluralism, correlation of objective laws and subjective factors in the imperatives of a competence model of education. The achieved results are aimed at practical realization in the field of pedagogical innovation.

Key words: education, management, innovation, competence, competency, motivation, methodological pluralism.

удк 378.1

Ольга Цибулько

Маріупольський державний університет ORCID ID 0000-0003-1297-5465

DOI 10.24139/2312-5993/2020.01/127-137

\section{ОСОБЛИВОСТІ ПЕДАГОГІКИ ДУХОВНОСТІ У СВІТЛІ СУЧАСНОГО СВІТСЬКОГО ТА РЕЛІГІЙНОГО ВИХОВАННЯ}

у статті окреслено відмінності між світським $i$ релігійним, а саме християнським, підходом до виховання духовності. обидві педагогічні моделі орієнтуються в справі виховання на найвищі стандарти духовного виховання. Однак, розуміння самої духовності в секулярній та релігійній педагогіці різняться.

Установлено, що духовне виховання й духовний досвід православної педагогіки сприймається у світській педагогіці, звичайно, як високий ідеал, проте, лише тією мірою, в якій розуміння християнської духовності відповідає власному розумінню духовності взагалі.

Розкрито специфріку православної педагогіки, яка, визнаючи необхідність всебічного розвитку людини, постулює швидше ієрархічне виховання учнів, під яким розуміється така «модель людини», яка має на увазі, що на першому місці з необхідністю повинні стояти духовні цінності (що розуміються, природно, в релігійному сенсі), потім тільки душевні й матеріально-фрізичні.

Ключові слова: світська педагогіка, релігійне виховання, духовна педагогіка, духовність, духовні чінності.

Постановка проблеми. Перш ніж окреслити відмінності між світським і релігійним, а саме християнським, підходом до виховання духовності, слід зазначити очевидну подібність, яка полягає в тому, що обидві педагогічні моделі орієнтуються в справі виховання на найвищі стандарти духовного виховання. Однак розуміння самої духовності в секулярній та релігійній педагогіці різняться. 